\title{
HEMŞiRELIK ÖĞRENCILERINDE PROBLEM ÇÖZME BECERISININ KLINIK KARAR VERME DÜZEYLERINE ETKISi
}

\author{
THE EFFECT OF PROBLEM SOLVING ABILITY ON CLINICAL DECISION MAKING \\ LEVELS IN NURSING STUDENTS
}

\author{
Canan DEMIR BARUTCU \\ Mehmet Akif Ersoy Üniversitesi Sağlık Bilimleri Fakültesi, İç Hastalıkları Hemşireliği ABD \\ Cite this article as: Demir Barutcu C. The Effect of Problem Solving Ability on Clinical Decision Making Levels in Nursing \\ Students. Med J SDU 2019; 26(1): 22-29.
}

Öz

\section{Amaç}

Bu çalışma hemşirelik öğrencilerinde problem çözme becerisinin klinik karar verme düzeylerine etkisini incelemek amacıyla yapılmıştır.

\section{Materyal ve Metod}

Tanımlayıcı ve korelasyonel nitelikte olan araştırmanın örneklemini bir devlet üniversitesinin sağlık bilimleri fakültesi hemşirelik bölümünde eğitim gören 231 öğrenci oluşturmuştur. Veriler, problem çözme envanteri ve hemşirelikte klinik karar verme ölçeği kullanılarak toplanmıştır.

\section{Bulgular}

Öğrencilerin yaş ortalaması $21.07 \pm 1.64$, \% 68.4'ü kadın, \%39'u ikinci sınıf öğrencisi olarak bulunmuştur. Öğrencilerin problem çözme becerilerinin yüksek olduğu, cinsiyet ve sınıf düzeyinin problem çözme becerileri anlamında fark yaratmadığı buna karşın bölümü isteyerek seçme, mesleği sevme, teorik bilgiyi uygulamaya yansıtma ve klinik uygulamada sorun yaşama durumlarına göre farklılıklar olduğu bulunmuştur $(p<0.05)$. Öğrencilerin klinik karar verme durumlarının iyi düzeyde olduğu, problem çözme becerileri ile hemşirelikte klinik karar verme ölçeği puan ortalamaları arasında güçlü, negatif yönde, istatistiksel olarak ileri düzeyde anlamlı bir ilişki olduğu belirlenmiştir ( $r$ $=-.565, p=.000)$. Öğrencilerinin problem çözme becerilerin klinik karar verme becerilerini olumlu yönde etkilediği bulunmuştur.

\section{Sonuç}

Elde edilen bulgular çerçevesinde hemşirelik öğrencilerinin problem çözme becerilerin klinik karar verme becerilerini etkilediği, öğrencinin klinik karar verme becerilerini arttırmak için eğitim müfredatlarında problem çözme becerilerini geliştirmek adına girişimler planlanması önerilmektedir.

Anahtar Kelimeler: Hemşirelik öğrencisi, klinik karar verme, problem çözme

\section{Abstract}

\section{Objective}

This study was undertaken to evaluate the effect of problem solving skills on clinical decision making levels in nursing students.

\section{Material and Method}

The sample of the study which has descriptive and correlational characteristics was composed of 231 students who get educated in the faculty of health sciences nursing department of a state university. The data were collected through problem-solving inventory and clinical decision-making scale in nursing.

\section{Results}

The average age of the students was determined as $21.07 \pm 1.64$, 68.4\% were female and $39 \%$ were at their second year of education. It was determined that problem solving skills of the students were high, gen-

İletişim kurulacak yazar/Corresponding author: canandemir2209@gmail.com Müracaat tarihi/Application Date: 09.05.2018 - Kabul tarihi/Accepted Date: 12.09.2018 CCopyright 2018 by Med J SDU - Available online at http://dergipark.gov.tr/sdutfd @Telif Hakkı 2018 SDÜ Tıp Fak Derg - Makaleye http://dergipark.gov.tr/sdutfd web sayfasından ulaşılabilir. 
der and level of class did not make any difference in terms of problem solving skills, on the other hand, differences were observed due to voluntarily choosing the department, loving the profession, having problems in implementing theoretical knowledge and clinical implementation $(p<0.05)$. It was determined that the condition of decision making of the students are at high level, and there was strong, negative statistically advanced level meaningful relation between the average scores of decision making skills and clinically decision making scale in nursing $(r=-.565, p=.000)$. It has been found that problem-solving skills of students positively influenced clinical decision-making skills.

\section{Conclusion}

Within the scope of findings obtained, it was determined that problem solving skills of nursing students effected clinical decision making skills and thus planning of initiatives is recommended to improve problem solving skills in education programs to improve clinical decision making skills of the student.

Keywords: Nursing student, clinical decision making, problem solving

\section{Giriş}

Problem; araştırılıp öğrenilmesi, üzerinde düşünülüp çözümlenmesi ve bir sonuca bağlanması gereken durum, problem çözme ise akılcı, bilinçli ve çaba gerektiren çok yönlü bir beceri olarak tanımlanmaktadır (1). Problem çözme sürecini etkileyen faktörler; zekâ, alışkanlık, toplumsal beklentiler, özgüven, düşünme yeteneği ve yaratıcılık düzeyi olarak belirlenmiştir (13). Günümüzde hızla gelişen teknoloji ve değişen sağlık bakım gereksinimleri nedeniyle hemşirelik mesleği problem çözebilen, araştırıcı, yaratıcı meslek üyelerine intiyaç duymaktadır (4). Hemşireler uygulama ortamlarında birçok problemle karşılaşmaktadır. Hemşirelerin güvenli ve kaliteli bakım sunmalarını belirleyen faktörlerden biri de problem çözme becerilerine sahip olma durumlarıdır. Klinik ortamda farkı sorunları olan bireylerle çalışmak durumunda kalan hemşirelerin problem çözme becerilerinin yüksek olması beklenmektedir (5). Hemşirelerin problem çözme becerilerinin gelişmiş olması, bakım verdiği bireylerin yaşamını koruma ve yaşam kalitesini arttırma sorumlulukları gereğidir (6). Hemşireler problem çözme becerilerini geliştirdiklerinde toplumun sağlığını koruma, geliştirme ve yaşam kalitesini artırma yönünde daha etkili hizmet verebilirler. Problem çözme becerisi yüksek bireylerin yaratıcı, yenilikçi, eleştirel düşünebilen, değişime açık bireyler olduğu belirtilmektedir (7). Problem çözme becerisi yüksek olan bireylerin sahip olduğu bu özellikler, profesyonel bir hemşireden beklenen mesleki özelliklerdir. Bu nedenle hemşirelik eğitiminde öğrencilerin problem çözme becerilerinin geliştirilmesi önemlidir (6). Hemşirelik öğrencilerinin problem çözme beceri düzeylerini inceleyen çalışmalarda, öğrencilerin problem çözme becerilerinin orta düzeyde olduğu ve birinci sınıfta öğrenim gören öğrencilerin problem çözme beceri düzeylerinin iki, üç ve dördüncü sınıf öğrencilerine göre daha düşük düzeyde olduğu bulunmuştur (8-10). Bireylerin problem çözme yöntemlerini bilmesi karşılaştığı problemleri çöze- bilmesi için yeterli olmayabilir bunun yanı sıra karşılaştığı soruna yönelik yaratıcı çözümler üretebilmesi gereklidir. Problemlerin çözülebilmesi için, disiplinler arası bilgi, çok yönlü yaratıcı düşünme ve karar verme becerisi gereklidir (11). Karar verme literatürde bir iş veya sorun hakkında düşünülerek verilen kesin yargı olarak tanımlanmaktadır (12). Karar verme süreci, birey tarafından bir durumun problem olarak tanımlanıp algılanması ile başlar, ulaşmak istenilen amaç için seçenekler arasından bir davranışın seçilmesini içeren zihinsel bir süreçtir (13). Karar verme süreci eleştirel düşünme becerisinin kullanılmasını gerektirir. Problemlere karşı çözüm üretmek için karar verme süreci önem taşımaktadır $(14,15)$. Karar verme üzerinde etkili bir değişken olan problem çözme becerisinin etkisine yönelik hemşirelik öğrencileriyle yapılan çaıışmalar sınırlıdır. Hemşirelik öğrencilerinde problem çözme ve klinik karar verme düzeylerinin saptanması, buna yönelik girişimler planlanmasını, geliştirilmesini sağlayabilir ve farkındalık yaratabilir. Bu nedenle çaIışma, hemşirelik öğrencilerin problem çözme becerisinin klinik karar verme düzeyine etkisini incelemek amacıyla yapılmıştır.

\section{Araştırma Soruları}

- Hemşirelik öğrencilerin problem çözme becerileri ne düzeydedir?

- Hemşirelik öğrencilerin klinik karar verme becerileri ne düzeydedir?

- Hemşirelik öğrencilerinin problem çözme becerisinin klinik karar verme becerisine etkisi ne düzeydedir?

- Hemşirelik öğrencilerinin problem çözme becerisi ile klinik karar verme becerisi arasında ilişki var mıdır?

\section{Gereç ve Yöntem}

$\mathrm{Bu}$ çalışma hemşirelik öğrencilerin problem çözme becerisinin klinik karar verme düzeyine etkisinin in- 
celenmesi amacıyla tanımlayıcı olarak yapılmıştır. Araştırmanın örneklemini, Mehmet Akif Ersoy Üniversitesi Sağlık Bilimleri Fakültesi'nde 2017-2018 yılında eğitim gören, araştırmaya katılmayı gönüllü olarak kabul eden ikinci, üçüncü ve dördüncü sınıf toplam 231 öğrenci oluşturmuştur. Araştırmaya katılan 12 öğrenci anket maddelerini eksik doldurduğu için örneklem dışında bırakılmıştır. Birinci sınıf hemşirelik öğrencilerinin örneklem dışı bırakılmasının nedeni klinik uygulama alanlarına çıkmamış olmalarıdır.

\section{Veri Toplama Araçları \\ Kişisel Bilgi Formu}

Öğrencilerin yaşı, cinsiyeti, sınıfı, bölümünü isteyerek seçme durumu, mesleği sevme durumu, teorik bilgiyi uygulamada kullanma durumu ve uygulamada sorun yaşama durumu olmak üzere yedi sorudan oluşmaktadır.

\section{Problem Çözme Envanteri (PÇE)}

Problem Çözme Envanteri; Heppner ve Peterson (1982) tarafından geliştirilmiş, Şahin ve Heppner (1993) tarafından Türkçeye uyarlamıştır. Ölçek 35 maddeden oluşan altılı likert tipinde bir ölçektir. Orijinal ölçeğin cronbach alfa güvenirlik katsayısı .90, Türkçe uyarlama çalışmasında bulunan güvenirlik katsayı .88 (16), bu çalışmada ise .86 olarak bulunmuştur. Ölçek seçenekleri "her zaman böyle davranırım" ile "hiçbir zaman böyle davranmam" şeklinde bir ve altı arası puanlanmaktadır. Ölçeğin puanlamasında 9, 22 ve 29 numaralı maddelere puan verilmez. 1, 2, 3, 4, 11, $13,14,15,17,21,25,26,30$ ve 34 numaralı maddeler ters olarak puanlandırılır. Ölçekten alınabilecek en düşük puan 32, en yüksek puan 192 olarak belirlenmiştir. Ölçeğin kesme noktası bulunmamaktadır. Ölçekten alınan puanın düşük olması problem çözme becerisinin yüksek olduğunu, yüksek olması problem çözme becerisinin zayıf olduğunu göstermektedir.

\section{Hemşirelikte Klinik Karar Verme Ölçeği (HKKVÖ)}

Jenkins (1983) tarafından geliştirilen ölçek Durmaz-Edeer ve Sarıkaya (2015) tarafından Türkçe'ye uyarlanmıştır. Orijinal ölçeğin cronbach alfa güvenirlik katsayısı 0.83 olarak, Türkçe formunun güvenirlik katsayısı ise 0.78 olarak bulunmuştur. Bu çalışma da ölçeğin cronbach alfa güvenirlik katsayısı 0.83 olarak bulunmuştur. Hemşirelikte Klinik Karar Verme Ölçeği, 40 madde ve dört alt boyuttan oluşmaktadır. Ölçeğin alt boyutları; "Seçenek ve fikirleri araştırmak", "Amaçları ve değerleri soruşturmak", "Sonuçları değerlendirmek" ve "Bilgiyi araştırmak ve bilgiyi tarafsız olarak benimsemek" olarak belirlenmiştir. Her alt boyut 10 maddeden oluşmaktadır. Ölçekte 22 madde $(1,3,5$, $7,8,9,10,11,14,16,17,18,20,26,27,28,29,33$,
$35,36,37,38)$ pozitif anlamlı iken 18 madde $(2,4$, $6,12,13,15,19,21,22,23,24,25,30,31,32,34$, $39,40)$ negatif anlamlıdır. Negatif anlamlı 18 madde ters puanlandırılmaktadır. Ölçeğin her bir maddesi 5 = Her zaman, 4 = sık sık, 3 = Ara sıra, 2 = Nadiren, 1 = Asla olarak değerlendirilmektedir (17). Ölçekten toplam 40 ile 200 arasında, her alt boyuttan 10 ile 50 arasında puan alınmaktadır. Ölçeğin kesme noktası bulunmamaktadır. Ölçekten alınan yüksek puan karar verme becerisinin yüksek olduğunu, düşük puan ise karar verme becerisinin düşük olduğunu göstermektedir $(17,18)$.

\section{Verilerin Değerlendirilmesi}

Veriler, SPSS 24.0 programı kullanılarak sayı, yüzde dağılımları, korelasyon, Student t-testi ile değerlendirilmiştir. Anlamlılık düzeyi $p<0.05$ olarak kabul edilmiştir. Sınıflara göre öğrencilerin problem çözme ve klinik karar verme becerilerini karşılaştırmak için tek yönlü varyans analizi (ANOVA) kullanılmıştır. Problem çözme ve klinik karar verme becerisi arasındaki ilişkiyi belirlemek için Pearson korelasyon testi uygulanmıştır. Korelasyon gücü $r=0.00-0.24$ zayıf, $r=0.25-0.49$ orta, $r=0.50-0.74$ güçlü, $r=0.75-1.00$ çok güçlü şeklinde değerlendirmeye alınmıştır (19).

\section{Araştırmanın Etik Yönü}

Araştırma için Mehmet Akif Ersoy Üniversitesi Sağlık Bilimleri Fakültesi Hemşirelik Bölüm Başkanlığı'ndan ve Mehmet Akif Ersoy Üniversitesi Girişimsel Olmayan Araştırmalar Etik Kurulu'ndan (GO 2018/71) yazılı izin alınmış, öğrencilere çalışmanın amacı açıklandıktan sonra gönüllü olarak katılmayı kabul eden öğrencilerden sözel izin alınmıştır.

\section{Bulgular}

Çalışmaya katılan öğrencilerin yaş ortalaması 21.07 \pm 1.64, \% 68.4'ü kadın, \% 39'u ikinci sınıf öğrencisi olarak bulunmuştur.

Öğrencilerin Hemşirelikte Klinik Karar Verme Ölçeği (HKKVÖ) puan ortalaması $144.26 \pm 15.39$ 'dir. Öğrencilerin Hemşirelikte Klinik Karar Verme Ölçeğinin alt boyut puan ortalaması incelendiğinde; "Seçenek ve fikirleri araştırmak $37.88 \pm 5.09$, "Amaçları ve değerleri soruşturmak" $34.44 \pm 3.89$, "Sonuçları değerlendirmek" $36.97 \pm 5.35$, Bilgiyi araştırmak ve bilgiyi tarafsız olarak benimsemek" ise $34.96 \pm 4.11$ olarak saptanmıştır. Öğrencilerin problem çözme envanterinden aldıkları puan ortalaması ise $89.39 \pm 18.58$ olarak bulunmuştur (Tablo 1).

Tablo 2'de öğrencilerin Hemşirelikte Klinik Karar Verme Ölçeği (HKKVÖ) alt boyut puan ortalamaları ve 


\begin{tabular}{|c|c|c|c|}
\hline \multicolumn{2}{|l|}{ Ölçekler } & \multirow{2}{*}{\begin{tabular}{|l}
$\begin{array}{l}\text { Alınan en düşük - } \\
\text { en yüksek puan }\end{array}$ \\
$24-49$ \\
\end{tabular}} & \multirow{2}{*}{\begin{tabular}{|l|}
$X \pm S S$ \\
$37.88 \pm 5.09$ \\
\end{tabular}} \\
\hline \multirow[t]{5}{*}{$\begin{array}{l}\text { Hemşirelikte Klinik Karar } \\
\text { Verme Ölçeği Alt Boyutları }\end{array}$} & $\begin{array}{l}\text { Seçenek ve fikirleri araştır- } \\
\text { mak }\end{array}$ & & \\
\hline & $\begin{array}{l}\text { Amaçları ve değerleri soruş- } \\
\text { turmak }\end{array}$ & $21-45$ & $34.44 \pm 3.89$ \\
\hline & Sonuçları değerlendirmek & $23-50$ & $36.97 \pm 5.35$ \\
\hline & $\begin{array}{l}\text { Bilgiyi araştırmak ve bilgiyi } \\
\text { tarafsız olarak benimsemek }\end{array}$ & $24-46$ & $34.96 \pm 4.11$ \\
\hline & Toplam Ölçek Puanı & $116-185$ & $144.26 \pm 15.39$ \\
\hline Problem Çözme Envanteri & Toplam Ölçek Puanı & $48-151$ & $89.39 \pm 18.58$ \\
\hline
\end{tabular}

problem çözme envanteri puan ortalamalarının bireysel özelliklerine göre dağılımları yer almaktadır. Hemşirelik 2., 3., ve 4. sınıf öğrencilerin HKKVÖ puan ortalamaları sırasıyla; $149.84 \pm 13.31 ; 141.79$ $\pm 16.22 ; 139.30 \pm 14.79$ olarak bulunmuştur. Hemşirelikte Klinik Karar Verme Ölçeği toplam puan ortalamalarının ve alt boyut ortalamalarının en yüksek 2 . sınıfta olduğu ve sınıf arttıkça puanın azaldığı, farkın istatistiksel olarak ileri düzeyde anlamlı olduğu saptanmıştır $(p<.01)$. Öğrencilerin HKKVÖ alt boyut puan ortalamalarının sınıflara göre istatistiksel olarak anlamlı olduğu bulunmuştur $(p<.05)$. Farkın hangi sınıftan kaynaklandığını belirlemek amacıyla Tukey testi yapılmıştır. İkinci sınıf öğrencilerinin klinik karar verme ölçeği puanlarının üçüncü ve dördüncü sınıflara göre anlamlı düzeyde yüksek olduğu, farkın ikinci sınıf puan ortalamasından kaynaklandığı belirlenmiştir (Tablo 2).

Öğrencilerin cinsiyete göre hemşirelikte klinik karar verme ölçeği puan ortalamaları arasındaki farkın anlamlı olduğu, kız öğrencilerin puan ortalamalarının daha yüksek olduğu bulunmuştur. Cinsiyete göre öğrencilerin hemşirelikte klinik karar verme ölçeği alt boyutları değerlendirildiğinde kız öğrenciler ile erkek öğrenciler arasındaki farkın anlamlı olduğu, kız öğrencilerin her alt boyutta puan ortalamalarının daha yüksek olduğu bulunmuştur $(p<.05)$. Öğrencilerin mesleği sevme durumlarına göre hemşirelikte klinik karar verme ölçeği puan ortalamaları arasındaki farkın anlamlı olduğu, mesleğini seven öğrencilerin puan ortalamalarının daha yüksek olduğu bulunmuştur. Aldığı teorik eğitimi uygulamaya yansıtan öğrencilerin hemşirelikte klinik karar verme ölçeği toplam puan ve alt boyut puan ortalamaları arasındaki farkın anlamlı olduğu, teorik eğitimi uygulamaya yansıtan öğrencilerin yansıtmayan öğrencilere kıyasla puan ortalamalarının daha yüksek olduğu bulunmuştur $(p<.05)$.

Öğrencilerin problem çözme envanteri puan ortalamaları bireysel özelliklere göre karşılaştırıldığında bölümü isteyerek seçme, mesleği sevme, teoriyi uygulamaya yansıtma ve uygulamada problem yaşama durumları arasında istatistiksel olarak fark olduğu ( $p$ $<$.05), bunun yanı sıra cinsiyet, sınıf düzeyine göre puan ortalamaları arasında fark olmadığı bulunmuştur $(p>.05)$.

Öğrencilerin problem çözme becerileri ile hemşirelikte klinik karar verme ölçeği puan ortalamaları arasında güçlü, negatif yönde, istatistiksel olarak ileri düzeyde anlamlı bir ilişki olduğu belirlenmiştir ( $r=-.565$, $p=.000)$. Öğrencilerin problem çözme becerileri ile hemşirelikte klinik karar verme ölçeğinin alt boyutları karşılaştırıldığında seçenek ve fikirleri araştırmak boyutuyla güçlü, negatif yönde, istatistiksel olarak ileri düzeyde anlamlı bir ilişki olduğu ( $r=-.556, p=.000)$, amaçları ve değerleri soruşturmak alt boyutuyla orta, negatif yönde, istatistiksel olarak ileri düzeyde anlamlı bir ilişki olduğu ( $r=-.359, p=.000)$, sonuçları değerlendirmek alt boyutuyla karşılaştırıldığında orta, negatif yönde, istatistiksel olarak ileri düzeyde anlamlı bir ilişki olduğu ( $r=-.470, p=.000)$, bilgiyi araştırmak ve bilgiyi tarafsız olarak benimsemek alt boyutuyla karşılaştırıldığında orta, negatif yönde, istatistiksel olarak ileri düzeyde anlamlı bir ilişki olduğu ( $r=-.473, p=$ .000) bulunmuştur (Tablo 3). 


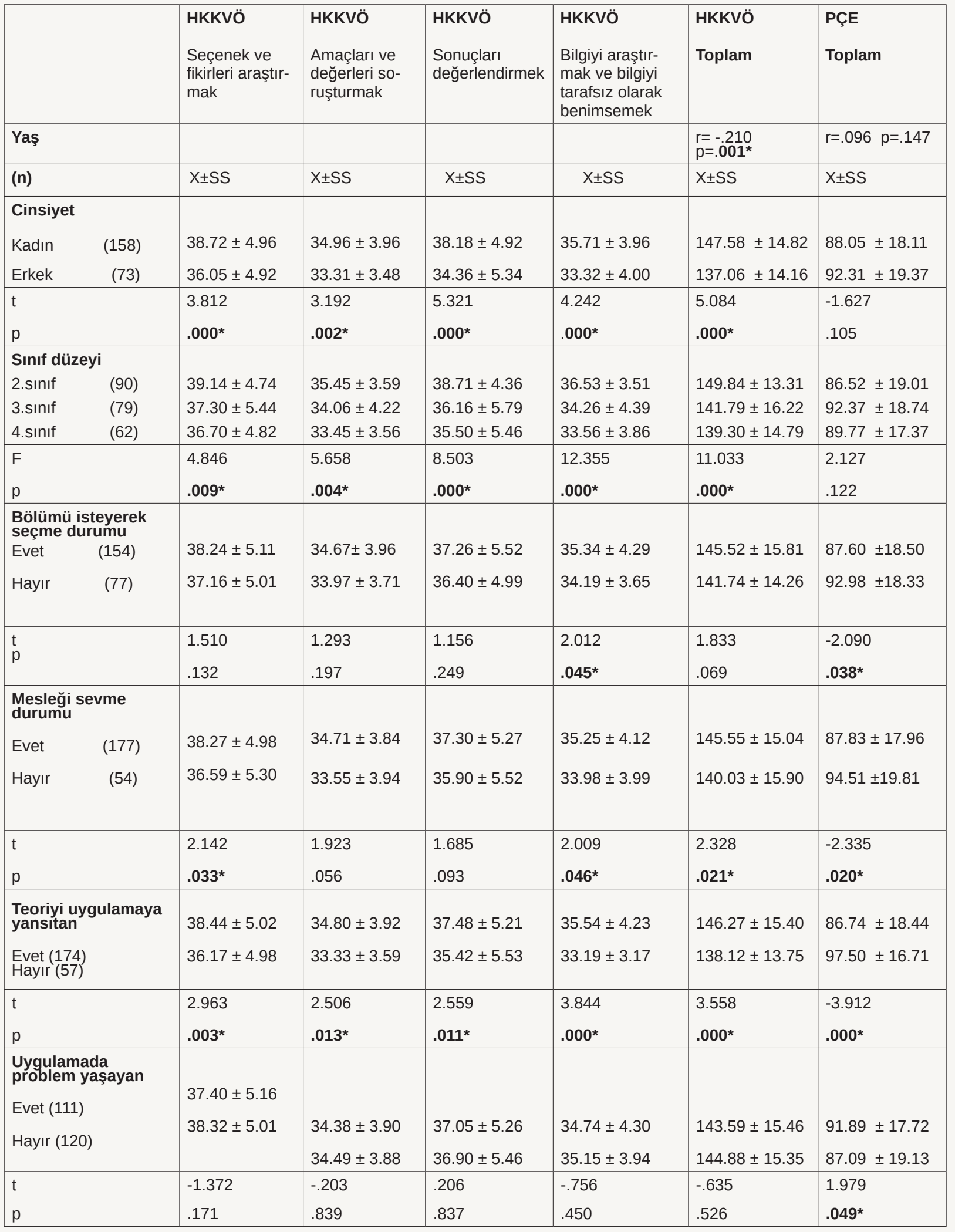

${ }^{*} p<0.05$ 


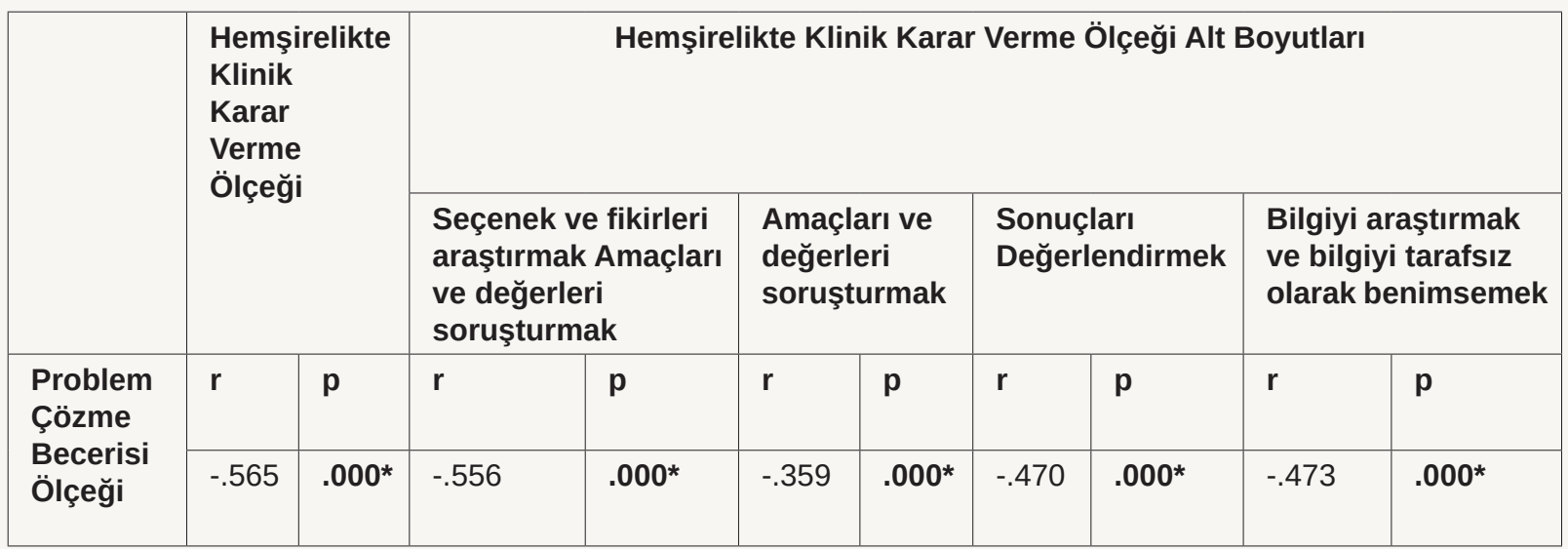

*p $<0.01$ düzeyinde anlamlı

\section{Tartışma}

Hemşirelik öğrencilerinin problem çözme becerilerinin klinik karar verme düzeyine etkisini ve aralarındaki ilişkiyi incelemek amacıyla yaptığımız bu çalışmada, hemşirelik öğrencilerinin problem çözme becerilerin oldukça iyi düzeyde olduğu bulunmuştur. Araştırma bulgularına göre öğrencilerin problem çözme becerileri puan ortalamalarının ortalama değerden daha düşük olması problem çözme becerilerinin yüksek olduğu anlamına gelmektedir. Öğrencilerin cinsiyeti ve sınıf düzeyi problem çözme becerileri anlamında fark yaratmamaktadır. Buna karşın bölümü isteyerek seçme durumları, mesleği sevme durumları, teorik bilgiyi uygulamaya yansıtma durumları ve klinik uygulamada sorun yaşama durumlarına göre farklılıklar bulunmaktadır. Literatürde öğrencilerin sınıf düzeylerine göre problem çözme becerilerini inceleyen çalışmalarda farkı sonuçlar bulunmaktadır. Öğrencilerin sınıf düzeyi artıkça problem çözme becerilerinde farklılık yarattığını belirten çalışmalar bulunmaktadır $(10,18,20)$. Bu çalışmalardan farklı olarak öğrencilerin sınıf düzeyinin problem çözme becerisine etkisinin olmadığı sonucuna ulaşan çalışmalarda bulunmaktadır $(21,22)$. Çalışmamızda problem çözme beceri puan ortalaması en düşük başka bir deyişle problem çözme becerisi en yüksek olan sınıf ikinci sınıf olarak bulunmuştur ancak aradaki fark istatistiksel olarak anlamsızdır. Kız öğrencilerin puan ortalamalarının erkek öğrencilere göre daha düșük olması problem çözme becerilerin daha iyi olduğunu göstermektedir ancak arada istatistiksel olarak farklılık bulunmamaktadır. Kız öğrencilerin sayısının erkek öğrencilere oranla fazla olmasının, gruplarının homojen olmamasının sonuçları etkileyebileceği düşünülmüştür.
Batıgün ve Kayış'ın (2014) üniversite öğrencilerinde problem çözme becerilerini incelediği çalışmasında problem çözme becerileri toplam puan ortalaması çaIışmamız puan ortalaması açısından benzerlik göstermektedir. Yıldııım ve arkadaşlarının (2011) öğrencilerin problem çözme becerilerini ve etkileyen faktörleri inceledikleri çalışmada öğrencilerin problem çözme beceri puan ortalaması çalışmamı puan ortalaması oldukça yakındır. Problem çözme becerisi sonradan öğrenilebilen ve geliştirilebilen beceriler olması nedeniyle eğitimin her aşamasında yer almalıdır (23). Abaan ve Altıntoprak'ın (2005) hemşirelerin problem çözme yeteneklerini değerlendirdiklerini çalışmada hemşirelerin problem çözme envanteri puan ortalaması çalışmamız puan ortalaması ile karşılaştırıldığında daha düşük bulunmuştur. Bu anlamda çalışmamızdaki hemşirelik öğrencilerinin puan ortalamalarının daha yüksek olması nedeniyle hemşirelerin hemşirelik öğrencilerine göre daha iyi problem çözdükleri düşünülmektedir. Kliniklerde sürekli problemlerle karşılaşan ve bu konuda deneyim kazanan hemşirelerin mesleğe yeni adım atan ve klinik uygulamadaki problemlerle yeni karşılaşan meslek adaylarına karşın daha iyi olmaları beklendik bir sonuçtur. Kanbay ve arkadaşIarının (2013) hemşirelik lisans öğrencilerinin problem çözme ve eleştirel düşünme becerilerini inceledikleri çalışmada sınıflara göre problem çözme beceri puan ortalamaları arasında farklılıklar bulunmasına karşın bu fark istatistiksel olarak anlamlı bulunmamıştır. Araştırma sonucu hem sınıflar arası farklılık olmaması hem de puan ortalaması açısından bizim puan ortalamamızla benzerlik göstermektedir. Tok ve Sevinç'in (2010) verilen eğitimin eleştirel düşünme ve problem çözme becerilerine etkisini inceledikleri çalışmada 
eğitim sonrasında öğrencilerin problem çözme becerileri puanlarının azaldığı bulunmuştur. Bu anlamda eğitimin problem çözme becerileri üzerine olumlu etkisi olduğu bulunmuştur.

Öğrencilerin klinik karar verme durumlarının ise iyi düzeyde olduğu bulunmuştur. Literatürdeki çalışmalar incelendiğinde çalışmamıza katılan öğrencilerin puan ortalamalarının, yapılan bazı çalışmalardan daha düşük ya da daha yüksek olduğu bulunmuştur (24-27). Öğrencilerin puan ortalamalarındaki farklılığın nedeni, bu çalışmaların farklı ülkeler, farklı eğitim sistemleri ve farklı müfredat içerikleri, farklı uygulama ortamlarından kaynaklanmış olabileceği düşünülmüştür. Literatürde öğrencilerin klinik karar verme becerilerinin sınıf düzeyi arttıkça klinik deneyim ile arttığı bildirilmektedir $(25,28,29)$. Ancak çalışmamızda hemşirelikte klinik karar verme ölçeği toplam puan ve alt boyut ortalamaları yönünden sınıf düzeyi arttıkça puan ortalaması azalmakta bașka bir deyișle klinik karar verme düzeyi azalmaktadır. Son sınıf öğrencilerin puan ortalaması ikinci ve üçüncü sınıf öğrencileri puan ortalamasına göre düşüktür. Araştırma bulgumuza benzer şekilde Dicle ve Edeer (2013), ikinci, üçüncü, dördüncü sınıf hemşirelik öğrencilerin klinik karar verme toplam puan ve alt boyut puan ortalamaları arasında fark olduğunu, ikinci sınıf öğrencilerin klinik karar verme puanlarının diğer sınıflara göre daha yüksek olduğunu bulmuştur. Öğrencilerin sınıfları arttıkça bilgi düzeylerinin artacağı düşünüldüğünde, çalışmamızda ikinci sınıf öğrencilerin hem klinik karar verme toplam puan hem de alt boyut puanlarının üçüncü sınıfa ve dördüncü sınıfa göre daha yüksek olduğu dikkat çekmektedir. İkinci sınıf öğrencilerin klinik uygulamaya yeni başlamaları, daha az hastaya bakım vermeleri ve bu süreçten deneyim kazanmaları ile diğer sınıflara kıyasla hem problem çözme becerileri hem de klinik süreçte problemlere karşı karar vermede daha güçlü ve daha yetkili hissettikleri görülmektedir. Bu durum mesleki uygulamaya yeni başlayan ve problemlerle yeni karşılaşan, teorik bilgi düzeyi eksik olan öğrencilerin kendilerini daha yetkin ve problem çözücü olarak görmelerinin ilerleyen süreçte sıkıntı yaratabileceği bu nedenle öğrencilerin bu tutumlarının yakından takip edilip değerlendirilmesi gerektiği düşünülmektedir. Çalışmamızda cinsiyetin öğrencilerin klinik karar verme düzeyi üzerinde etkisi olduğu bulunmuştur. Kız öğrencilerin erkek öğrencilere oranla karar verme düzeylerin daha iyi olduğu bulunmuştur. Aradaki farkın örneklem sayısındaki farklılıktan kaynaklanabileceği düşünülmüştür. Çalışmamızda, hemşirelik bölümünü isteyerek seçen, hemşirelik mesleğini seven, teorik bilgisini uygulamaya yansıtan öğrencilerin klinik karar verme puan ortalamasının daha yüksek olduğu bulunmuştur. Çalışma sonucumuzla benzer olarak Özden ve arkadaşlarının (2018) yaptığı çalışmada hemşirelik mesleğinden memnun olan, bölüme isteyerek gelen öğrencilerin klinik karar verme düzeylerinin istatistiksel olarak anlamlı olduğu bulunmuştur. Hemşirelerin kendine güvenmesinin; etkili ve doğru karar vermede önemli rol oynadığı bilinmektedir (30). Bu anlamda çalışma sonucumuz literatürü destekler niteliktedir.

Öğrencilerin problem çözme becerileri ile hemşirelikte klinik karar verme ölçeği toplam puan ve alt boyut puan ortalamaları incelendiğinde öğrencilerin problem çözme becerileri geliştikçe klinik karar verme becerilerin arttığı bulunmuştur.

Problem çözme ve karar verme faaliyetlerin ilk bölümü hedeflerin belirlenmesi ve hareket tarzlarının oluşturulması, problem çözme olarak tanımlanırken, değerlendirme ve seçim, karar verme basamakları olarak adlandırılır. Karar verme davranışları; bireylerin psikolojik, kişilik, demografik özelliklerine göre değişmektedir (13). Bu nedenle bireylerin karar verme davranışları değerlendirilirken bu parametrelerin incelenmesi gerekmektedir. Öğrenciler klinik ortamlarda, teorik bilgi ve beceri eksikliği, iletişim problemleri gibi problemler yaşayabilmekte bu da öğrencilerin klinik karar vermelerini olumsuz yönde etkileyebilmektedir (31).

\section{Sonuç ve Öneriler}

Bu çalışma sonucunda öğrencilerin problem çözme becerilerin ve klinik karar verme durumlarının iyi düzeyde olduğu belirlenmiştir. Hemşireler, bakım verme sürecinde karşılaştıkları problemlere çözüm bulmada, gelişen teknolojiye uyum sağlamada ve bakımın kalitesini artırmada becerilerini geliştirmelidir. Hemşirelik eğitimi veren okullarda problem çözme becerilerini geliştirecek girişimler planlanmalı, çözüm önerileri yaratılmalı ve kliniğe yansıtılmalıdır. Çalışma sonucuna göre öğrencilerin klinik karar verme düzeyini bölüme isteyerek gelme, hemşirelik mesleğini sevme, klinik uygulamada sorun yaşamama, teorik bilgiyi klinik uygulamada kullandığını düşünme gibi değişkenlerin etkilediği saptanmıştır. Sınıf düzeyi arttıkça klinik karar verme düzeyinin azalması, karar verme beceri puan ortalamalarının en yüksek ikinci sınıf öğrencilerinde olmasının nedeninin kalitatif çalışmalarla ortaya çıkarılması gerektiği düşünülmektedir. Problem çözme, klinik karar verme düzeyini etkileyen değişkenlerden sadece biridir, bu anlamda karar vermeyi etkileyebilecek farklı değişkenlerle farklı örneklem gruplarında araştırılması önerilmektedir.

\section{Sonuçların Uygulamada Kullanımı}

Elde edilen bulgular çerçevesinde hemşirelik öğren- 
cilerinin problem çözme becerilerin klinik karar verme becerilerini etkilediği, öğrencinin klinik karar verme becerilerini arttırmak için eğitim müfredatlarının problem çözme becerilerini geliştirmek adına gözden geçirilmesi yararlı olabilir.

\section{Kaynaklar}

1. Gomez JG. What do we know about creativity? Journal of Effective Teaching 2007;7 (1): 31-43.

2. Otacioglu SG. "Comparison of Problem Solving Skills Levels of Students in Different Branches of Education Faculties ", Journal of Eurasian Educational Researches 2007; 29: 73-83

3. Özer B, Gelen I, Öcal S. Analysis of the Effect of the Leisure Habits of the Secondary Grade Students on the Problem Solving Abilities of the Daily Students Mustafa Kemal University Journal of Social Sciences 2009; 6 (2): 235-257

4. Şen H, Yılmaz F, Gürdogan P. Creativity in Nursing Journal of Academic Review 2103; 38: 1-8.

5. McEwen M, Brown SC. Conceptual frameworks in undergraduate nursing curricula: report of a national survey. Journal of Nursing Education 2002;41(1): 5-14

6. Abaan S, Altıntoprak A. Problem solving skills in nurses: analysis of self-evaluation results. Hacettepe University University Journal of Nursing School 2005:62-76.

7. Nezu AM, Nezu MN. Problem solving therapy. Journal of Psychotherapy Integration 2001;11: 197-205.

8. Yurttaş A, Yetkin A. Comparison of empathic skills and problem solving skills of health college students. Ataturk University Journal of Nursing School 2003; 6 (1): 1-6

9. Gönülal A, Bahar Z. Self-learning and problem-solving skills in nursing students' probing-based learning model. II. Active Education Congress Book (Congress Book). Izmir. 4-5 June 2005; 332-343.

10. Günüşen N, Üstün B. The Relationship Between Problem Solving Skills Levels of Nursing Students and Control Parents. DEUHYO ED 2011; 4 (2): 72-77

11. Mertoğlu H, Öztuna A. "How Does Individual Use of Technology Relate to Problem Solving Abilities? ", The Turkish Online Journal of Educational Technology 2004; 3(1): 12.

12. www.tdk.gov.tr (Accesed:12.04.2018)

13. Yaşar O. Behavioral Decision Making Thinking, Problem Solving, 1st Edition, Detay Publishing, Ankara, 2016

14. Cüceloğlu D. İyi Düşün Doğru Karar Ver. System Publishing. İstanbul 2000.

15. Taşçı S. Problem Solving Process in Nursing The Problem Solving Process In Nursing Journal of Health Sciences (Supplement: Nursing Special Issue) 2005; 14: 73-78.

16. Şahin N, Heppner P. Psychometric properties of the problem solving in a group of turkish university students. Cognitive Therapy and Research 1993;17(4): 379- 396.

17. Jenkins $\mathrm{H}$. Perceptions of decision making among baccalaureate nursing students as measured by the clinical decision making in nursing scale. University of Maryland, Doctors of thesess. 1983. Erişim tarihi: Şubat 2018.

18. Durmaz S, Kaçar Z, Can S, Koca R, Yeşilova D, Tortumluoğlu G. Problem solving skills and some factors affecting Çanakkale health college students. Ataturk University Journal of Nursing School 2007; 10 (4): 63-71.

19. Aksakoğlu G. Health Research and Analysis, 2nd Printing, Izmir, D.E.U. Rectorate Printing House 2006; 283-300

20. Beşer A, Kıssal A. Critical thinking dispositions and problem solving skills among nursing students. Dokuz Eylül University School of Nursing Electronic Journal 2009;2(3): 88-94.

21. Altun $\mathrm{i}$. The perceived problem solving ability and values of student nurses and midwives. Nurse Education Today 2003;23: 575-584.
22. Tezel A, Arslan S, Topal M, Aydoğan Ö, Koç Ç, Şenlik M. Examination of problem solving skills and depression levels of nursing students. Atatürk University Nursing School Magazine 2009;12 (4): 63-71.

23. Yıldırım A, Hacıhasanoğlu R, Karakurt P, Türkleş S. Problem Solving Skills and Affecting Factors of High School Students, International Journal of Human Sciences 2011;8(1):906-921.

24. Özden D, Özveren H, Gülnar E. Clinical Decision Making Levels and Factors Affecting Nursing Students.DEUHFED 2018; 11 (1): $41-47$

25. Dicle A, \& Edeer AD. Examination of clinical decision making perceptions of nursing students. The New Educational Review 2013;33 (3): 134-144.

26. Ho SE Koo, YL, Ismail S, Hing HL, Widad O, Chung HT, et al. Clinical decision making ability of nursing students in a tertiary hospital. Medicine \& Health 2013;8: 73-80.

27. Krumwiede AK. An examination of accelerated and basic baccalaureate nursing students' perceptions of clinical decision making, Capella University, Doctor of Philosophy, UMI Number: 2010.

28. Atasoy I, Sütütemiz N. A group of nursing senior students' views on nursing education. Florence Nightingale Nursing Journal 2014;22 (2): 94-104.

29. Bulut S, Ertem G, Sevil Ü. Examination of nursing students' level of critical thinking. Dokuz Eylül University Faculty of Nursing Electronic Journal 2009; 2 (2): 27-38.

30. Sucu G, Dicle A, Saka O. Clinical decision making in nursing, affecting factors and decision making models. Education and Research Journal in Nursing 2012;9 (1): 52-60.

31. Bektaş I, Yardımcı F, Bektaş M, White KA. Psychometric properties of the Turkish version of nursing anxiety and self confidence with clinical decision making scale (NASC-CDM-T). Dokuz Eylül University Faculty of Nursing Electronic Journal 2017;10 (2): 83-92. 